\title{
A Comparative KAP Study on Ragi, A Forgotten Wonder Grain with Oats among South Indian Families
}

\author{
Shaji Sreedhar KP ${ }^{1 *}$ and Sripriya Shaji ${ }^{2}$ \\ ${ }^{1}$ Department of Biochemistry, Government Medical College, Kozhikode, India \\ ${ }^{2}$ Nutritionist \& Psychologist, Sripriya's counseling centre, India
}

Submission: June 19, 2017; Published: July 26, 2017

*Corresponding author: Shaji Sreedhar KP, Department of Biochemistry, Government Medical College, Kozhikode, India, Tel: +91 9496221446; Email ID: drshajisreedhar@gmail.com

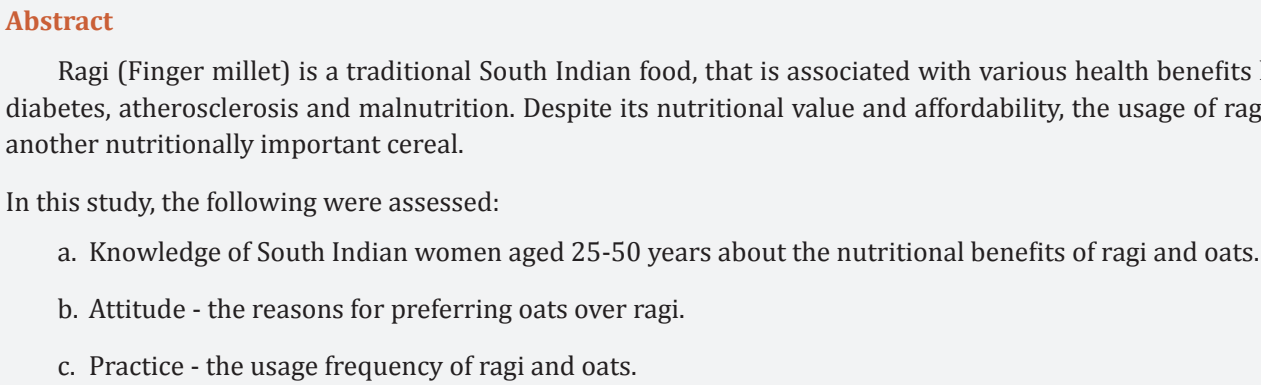
another nutritionally important cereal.

In this study, the following were assessed:

a. Knowledge of South Indian women aged 25-50 years about the nutritional benefits of ragi and oats.

b. Attitude - the reasons for preferring oats over ragi.

c. Practice - the usage frequency of ragi and oats.

Ragi (Finger millet) is a traditional South Indian food, that is associated with various health benefits like reduction of cholesterol, obesity, diabetes, atherosclerosis and malnutrition. Despite its nutritional value and affordability, the usage of ragi is minimal when compared to oats,

The study reveals that most of the people were ignorant about nutritional benefits of ragi in comparison to oats, an adopted food. The scores are above 6 out of 10 (mean score $7.5 \pm 1.1$ ) for oats and less than 5 out of 10 (mean score $3 \pm 0.8$ ) for ragi. The common reasons cited for preferring oats over ragi were less cooking time (95\%), inspiration from advertisements and friends (94\%) and ignorant about health benefits of ragi (91\%). From this study, it was observed that $61.5 \%$ people use oats everyday whereas only $11.5 \%$ use ragi. In spite of having favourable growing conditions for cultivation and less priced than oats, there is decreased use of ragi as a staple food. Hence it is important to create awareness among the people and encourage its use.

Keywords: Ragi; Oats; KAP; Calcium; Anti-oxidants

\section{Opinion}

Ragi or finger millet (Eleusine Coracana) is one of the common cereal grown in India and a traditional food of South Indians since 1800 BC [1]. Though Indians consume cereals as the main staple providing $70-80 \%$ of total energy intake [2], the consumption of millets is very low compared to rice. A study by CURES (Chennai Urban Rural Epidemiology Studies) revealed that millets contributed to only about $2 \%$ of total calories [3], while almost half of the daily calories were derived from refined grains [4]. Another study [5], reported that the consumption of millets (consumption unit is a coefficient and $1 \mathrm{CU}$ corresponds to energy requirement of $2400 \mathrm{kcal} /$ day of an Indian male doing sedentary work) was $75 \mathrm{~g} / \mathrm{CU} /$ day in Karnataka, $16 \mathrm{~g} / \mathrm{CU} /$ day in Andhra Pradesh, 3g/CU/day in Tamil Nadu and almost nil in Kerala. The increase in the incidence of lifestyle disorders

like diabetes mellitus, systemic hypertension, dyslipidemia and obesity has lead to alternative adoption of foods like oats, which has high content of dietary fibres, phytochemicals, hypocholesterolaemic and anticancerous properties. However because of less favourable growing conditions in India, a higher proportion of oats consumed is chiefly imported, thereby increasing its cost.

Even though there are so many other millets like ragi which also possess similar health benefits and are comparatively cheaper, there is ignorance among people regarding their nutritional content. Hence this study was undertaken to assess the knowledge of South Indian women about the nutritional benefits of both ragi and oats, the frequency of usage and the reasons for preferring oats over ragi. 


\section{Current Research in Diabetes \& Obesity Journal}

\section{Methodology}

A cross-sectional study was conducted among 260 South Indian women with age ranging from 25 to 50 years (mean age of $37.5 \pm 7.5$ ), who involve in purchase of grocery and cooking for their families irrespective of their socio-economic status and education. A semi-structured questionnaire was designed to test the knowledge about nutritional benefits of ragi and oats for the score of 10 each. The frequency of usage was assessed with 3 point rating scale-daily, often (at least once in a week) and occasionally (during festivals and functions). An open question was asked to know the reasons for preferring ragi over oats and the responses were recorded and organized into categories by the researcher. Informed consent was taken from all the respondents for data collection. Descriptive and inferential statistics (t-test) were calculated.

\section{Results}

\section{Knowledge}

Every respondents knowledge about nutritive benefits of oats and ragi was assessed out of a total score of 10 . The range of score about nutritive benefits of oats was from 6 to 9 (mean score $7.5 \pm 1.1$ ), higher than that of ragi, which was ranging from 2 to 4 (mean score $3 \pm 0.8$ ). The difference between the scores for both oats and ragi by the same individual varied from 2 to 7 (mean score $4.5 \pm 1.3$ ). The t-test for two scores were done assuming unequal variance with hypothesis of mean difference 4.5 , which is the mean value of the difference between the scores for nutritive benefits of oats and ragi. The observed difference between the mean (7.5-3) is not convincing enough to say that the average knowledge about nutritive benefits of oats and ragi differ significantly ( $p$ value $=0.9$ ) (Table 1 ). However the range of score proves that the knowledge about ragi is lesser than oats.

Table 1: Scores of knowledge about nutritive benefits of oats and ragi.

\begin{tabular}{|c|c|c|c|}
\hline Variable & Mean & Std Dev & T-Test \\
\hline Oats & 7.51 & 1.12 & \multirow{2}{*}{$0.90^{*}$} \\
\cline { 1 - 3 } Ragi & 3.00 & 0.82 & \\
\hline Difference & 4.50 & 1.32 & \\
\hline
\end{tabular}

\section{Attitude}

\section{REASONS FOR PREFERRING OATS OVER RAGI}

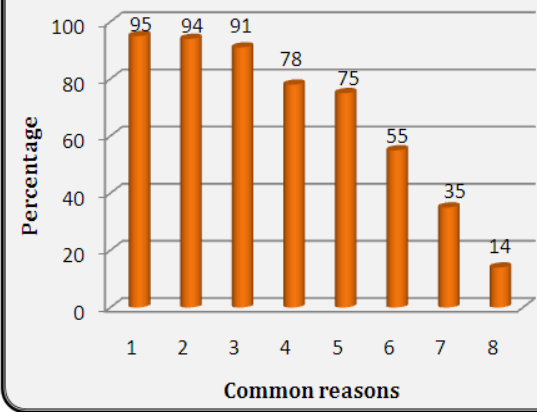

Common Reasons: 1. Less cooking time \& convenience 2. Inspiration from advertisements \& friends

3. Ignorant of nutritional benefits 4. Colour \& texture 5. Social status 6. Palatability 7. Health experts advice

8. Bored of cooking traditional foods

Figure 1: Reasons for preferring oats over ragi.
The study reveals that the most common reasons for preferring oats over ragi (Figure 1) were less cooking time and convenience (95\%), inspiration from advertisements and friends (94\%) ignorance about nutritional benefits of ragi (91\%), colour and texture (78\%), social status (75\%), palatability (55\%), health experts advice (35\%) and bored of cooking traditional varieties $(14 \%)$.

\section{Practice}

From the study, it was observed that $61.5 \%$ of participants use oats on daily basis, whereas only $11.5 \%$ use ragi. Almost $32 \%$ use oats and $25 \%$ use ragi at least once in a week. The occasional use percentage of ragi: oats is 63.5: 6.5.

\section{Discussion}

Since the seed coat of ragi is five layered, it has more dietary fibre content $(11.5 \mathrm{~g})[2,6]$ than oats $(10.6 \mathrm{~g})$ [7], which include polysaccharides such as $\beta$-glucan, arabinoxylans and cellulose. They reduce the rate of cholesterol absorption by increasing the viscosity of gut contents [8] and causes binding of bile acids to increase the excretion of cholesterol [9]. Short chain fatty acids like butyric acid, which are produced by fermentation of dietary fibres in the large intestine are involved in countering colon cancer by modulating gene expression and inducing apoptosis [10]. Dietary fibre also serve as a substrate for gut microflora and promotes laxation [11]. Even though the concentration of proteins is low in ragi than oats, the prolamine fraction is high [12]. Prolamine contains the higher proportion of glutamic acid, proline, valine, isoleucine, leucine and phenylalanine. They are gluten-free [13] and are safe to be used in persons with celiac disease. The lipid content of oats $(6.9 \mathrm{~g})$ is higher than ragi $(1.3 \mathrm{~g})$ which causes poor flavour and excessive browning. It also has higher amount of lipases that cause rancidity and short storage life [14].

The calcium content of ragi (344mg) is higher than oats (54mg). Micronutrients like molybdenum, chromium, sulphur and vitamins like carotene, folic acid and choline are present in ragi while they are negligible in oats. Though vitamin $\mathrm{C}$ is absent in both ragi and oats, ascorbic acid is formed in ragi during the process of germination and therefore the iron in ragi is easily absorbed [15]. Ragi is a very good source of phenolic compounds [16,17] like ferulic acid, caffeic acid and vanillic acid [18]. Polyphenols play a very important role in enhancing endothelial function [19], cellular signalling and anti inflammation [20], free radicals scavenging [21] and anti oxidant effect [22]. They also lower blood glucose by effective inhibition of $\alpha$-glucosidase, pancreatic $\alpha$-amylase and fructose induced albumin glycation [23]. In spite of having more nutritional value (Table 2), the usage of ragi is minimal mainly because of unawareness among the people regarding its health benefits. The convenience of easy cooking, advice from friends and health experts, colour, texture, palatability and a symbol of social status were other reasons for preferring oats. Even though $14 \%$ of people were 


\section{Current Research in Diabetes \& Obesity Journal}

bored of cooking traditional varieties, still ragi gained a higher occasional use in festive seasons. The glycemic response (GR) of oats is generally lower than ragi. In most of the studies, GR was measured from venous samples but newer guidelines necessitate capillary glucose samples because of its greatest sensitivity for glycemic index (GI). Hence more studies and researches are further needed to determine the glycemic response for different preparations of ragi [24].

Table 2: Nutrients, vitamins and minerals composition of ragi and oats (all values are per $100 \mathrm{~g}$ of edible portion).

\begin{tabular}{|c|c|c|}
\hline Parameter & Ragi & Oatmeal \\
\hline Moisture (g) & 13.10 & 8.22 \\
\hline Protein $\left(\mathrm{N}^{*} 6.25\right)(\mathrm{g})$ & 7.30 & 16.89 \\
\hline Fat (g) & 1.30 & 6.90 \\
\hline Dietary fibre (g) & 11.50 & 10.60 \\
\hline Carbohydrates (g) & 72.00 & 66.00 \\
\hline Energy (kcal) & 328.00 & 389.00 \\
\hline \multicolumn{3}{|c|}{ Vitamins } \\
\hline Pantothenic acid & & 1.35 \\
\hline Carotene $(\mu \mathrm{g})$ & 42.00 & 0.00 \\
\hline Thiamine (mg) & 0.42 & 0.76 \\
\hline Riboflavin (mg) & 0.19 & 0.14 \\
\hline Niacin (mg) & 1.10 & 0.96 \\
\hline Total B6 (mg) & & 0.12 \\
\hline \multicolumn{3}{|l|}{ Folic acid $(\mu \mathrm{g})$} \\
\hline Free & 5.20 & 0.00 \\
\hline Total & 18.30 & \\
\hline Vitamin C (mg) & 0.00 & 0.00 \\
\hline \multicolumn{3}{|c|}{ Minerals and trace elements } \\
\hline Calcium (mg) & 344.00 & 54.00 \\
\hline Phosphorus (mg) & 283.00 & 523.00 \\
\hline Iron (mg) & 3.90 & 4.72 \\
\hline Magnesium (mg) & 137.00 & 177.00 \\
\hline Sodium (mg) & 11.00 & 2.00 \\
\hline Potassium (mg) & 408.00 & 429.00 \\
\hline Copper (mg) & 0.47 & 0.63 \\
\hline Manganese (mg) & 5.49 & 4.92 \\
\hline Molybdenum (mg) & 0.10 & \\
\hline Zinc (mg) & 2.30 & 3.97 \\
\hline Chromium (mg) & 0.03 & \\
\hline Sulphur (mg) & 160.00 & \\
\hline Chlorine (mg) & 44.00 & \\
\hline
\end{tabular}

\section{Limitations}

a. The sample size small when compared to the actual population.

b. The study is limited by its reliance on retrospective self-report measures.

\section{Conclusion}

India is a country leading in both the spectrum of life-style diseases and malnutrition. The consumption of ragi is associated with reduction of total plasma cholesterol, post-prandial blood glucose, obesity, atherosclerosis, development of cancer, rickets and osteoporosis. Ragi is superior to oats in bioavailability of minerals. The climatic conditions in India does not favour cultivation of oats and hence it is chiefly imported. However ragi has favourable growing conditions, which makes it economically affordable than oats. Our study revealed that the ignorance about nutritional benefits of ragi has led to its decreased usage. Hence it is important to create awareness among the people regarding its health benefits and encourage the use of ragi.

\section{References}

1. KT Achaya (2003) Indian archaeological site. The Story of Our Food. Universities Press, India, p. 21.

2. Gopalan C, Rama Sastri BV, Balasubramanian SC (1989) Nutritive value of Indian foods. National Institute of Nutrition, Indian Council of Medical Research, India, p. 156.

3. Radhika G, Sathya RM, Ganesan A, Saroja R, Vijayalakshmi P, et al. (2011) Dietary profile of urban adult population in south India in the context of chronic disease epidemiology (CURES-68). Public Health Nutr 14(4): 591-598.

4. Radhika G, Van Dam RM, Sudha V, Ganesan A, Mohan V (2009) Refined grain consumption and the metabolic syndrome in urban Asian Indians (Chennai Urban Rural Epidemiology Study 57). Metabolism 58(5): 675-681.

5. National Nutrition Monitoring Bureau NNMB (2006) Diet and nutritional status of rural population and prevalence of hypertension among adults in rural areas. NNMB Technical Report 24. National Institute of Nutrition, Indian Council of Medical Research, India, pp. 1-166.

6. Geervani P, Eggum BO (1989) Nutrient composition and protein composition of minor millets. Plant Foods Hum Nutr 39(2): 201-208.

7. USDA National Nutrient Database for Standard Reference 28 slightly revised May 2016. New Zealand, pp. 1-2.

8. Wang L, Newman RK, Newman CW, Hofer PJ (1992) Barley $\beta$-glucan alters intestinal viscosity and reduces plasma cholesterol concentration in chicks. J Nutr 122(11): 2292-2297.

9. Kahlon TS, Chow FL, Knuckles BE, Chiu MM (1993) Cholesterol lowering effects in hamsters of $\beta$-glucan-enriched barley fractions, dehulled whole barley, rice bran, and oat bran and their combinations. Cereal Chem 70: 435-440.

10. Hsueh CW, Chia HH, Jeng DH, Mon YY, Shing JW, et al. (2011) Inhibitory effect of whole oat on aberrant crypt foci formation and colon tumor growth in ICR and BALB/c mice. J Cereal Sci 53(1): 73-77.

11. Schneeman BO (2001) Dietary fibre and gastrointestinal function. In: McCleary BV, Prosky L (Eds.), Advanced dietary fibre technology. Blackwell Science, UK, pp. 168-170. 


\section{Current Research in Diabetes \& Obesity Journal}

12. Virupaksha TK, Ramachandra G, Nagaraju D (1975) Seed proteins of finger millet and their amino acid composition. Journal of the Science of Food and Agriculture 26(8): 1237-1246.

13. Thompson $\mathrm{T}$ (2009) The nutritional quality of gluten-free foods in Gluten-Free Food Science and Technology. In: Gallagher E (Ed.), Oxford: John Wiley and Sons Ltd, UK, pp. 42-51.

14. Lehtinen P, Kiiliaeinen K, Lehtomaeki I, Laakso S (2002) Effect of heat treatment on lipid stability in processed oats. Journal of Cereal Science 37(2003): 215-221.

15. Tatala S, Ndossi G, Ash D, Mamiro P (2007) Effect of germination of finger millet on nutritional value of foods and effect of food supplement on nutrition and anaemia status in Tanzanian children. Tanzan Health Res Bull 9(2): 77-86.

16. Chethan S, Malleshi NG (2007a) Finger millet polyphenols: Characterization and their nutraceutical potential. American Journal of Food Technology 2(7): 582-592.

17. Chethan S, Malleshi NG (2007b) Finger millet polyphenols: Optimization of extraction and the effect of $\mathrm{pH}$ on their stability. Food Chemistry 105(2): 862-870.

18. Matilla P, Pihlava JM, Hellstrom J (2005) Contents of phenolic acids, alkyl and alkylresorcinol and avenanthramides in commercial grain products. J Agric Food Chem 53(21): 8290-8295.
19. Caton PW, Pothecary MR, Lees DM, Khan NQ Wood EG, et al. (2010) Regulation of vascular endothelial function by procyanidin-rich foods and beverages. J Agric Food Chem 58(7): 4008-4113.

20. Ramos S (2008) Cancer chemoprevention and chemotherapy: dietary polyphenols and signalling pathways. Mol Nutr Food Res 52(2): 507526.

21. Sripriya G, Chandrasekharan K, Murthy VS, Chandra TS (1997) ESR pectroscopic studies on free radical quenching action of finger millet (Eleusine coracana). Food Chemistry 57(4): 537-540.

22. Varsha V, Urooj A, Malleshi NG (2009) Evaluation of antioxidant and antimicrobial properties of finger millet (Eleusine coracana) polyphenols. Food Chemistry 114(1): 340-346.

23. Shobana S (2009) Investigations on the carbohydrate digestibility of finger millet with special reference to the influence of its seed coat constituents. Thesis University of Mysore, India.

24. Shobana S, Krishnaswamy K, Sudha V, Malleshi NG, Anjana RM, et al. (2013) Finger Millet (Ragi, Eleusine coracana L.): A Review of Its Nutritional Properties, Processing, and Plausible Health Benefits. Adv Food Nutr Res 69: 1-39.

Your next submission with Juniper Publishers will reach you the below assets

- Quality Editorial service

- Swift Peer Review

- Reprints availability

- E-prints Service

- Manuscript Podcast for convenient understanding

- Global attainment for your research

- Manuscript accessibility in different formats

( Pdf, E-pub, Full Text, Audio)

- Unceasing customer service

Track the below URL for one-step submission https://juniperpublishers.com/online-submission.php 